\title{
Effect of dietary replacement of fish meal by mixture of different plant protein sources on growth performance and some blood parameters of Nile tilapia, Oreochromis niloticus
}

\author{
Magdy A. Soltan ${ }^{1}$ and Ahmed F. Fath El-Bab ${ }^{2}$ \\ 1- Department of Animal Production, Faculty of Agriculture, Moshtohor, Benha \\ University, Egypt \\ 2- Central Laboratory for Aquaculture Research at Abassa, Sharkia Governorate.
}

Key words: replacement, fish meal, plant protein mixture, growth, Nile tilapia

\begin{abstract}
$\mathrm{T}$ his study was designed to determine the maximum replacing levels of fish meal (FM) by a plant protein mixture (PPM) in eight diets for Nile tilapia. The PPM consisted of cottonseed, sunflower, canola, seasme and linseed meals. FM in the basal diet was replaced by PPM in the diets at a replacing levels of 15 , $30,45,60,75,90$ and $100 \%$. A total number of 480 Nile tilapia were randomly distributed into eight treatments, each in three replicates.

After 12 weeks of feeding, results revealed that replacement of 15,30 or $45 \%$ of FM by PPM did not significantly affect feed intake (FI), feed conversion ratio (FCR), protein efficiency ratio (PER), and the apparent digestibilities coefficient (ADC) of dry matter (DM), crude protein (CP) and ether extract (EE), while the higher replacing levels $(60,75,90$ or $100 \%)$ significantly $(\mathrm{P}<0.05)$ reduced these parametesr. Growth parameters were relatively parallel to those of FI, FCR and PER, whereas replacement up to $45 \%$ exhibited body weight $(\mathrm{BW})$, body length $(\mathrm{BL})$, weight gain $(\mathrm{WG})$ and specific growth rate (SGR) not differing significantly $(\mathrm{P}<0.001)$ from the fish fed on control diet. Compared to control diet, increasing PPM in the diets significantly reduced hemoglobin, hematocrit and increased the activity of alanine aminotransferase (ALT) and aspartate aminotransferase (AST). The incorporation of PPM in diets did not significantly affect the whole-body dry matter (DM) and crude protein (CP).

From economic point of view, replacement of FM by PPM up to $45 \%$ in tilapia diets reduced feed costs $/ \mathrm{kg}$ diet and feed costs $/ \mathrm{kg}$ weight gain by 11.40 and $6.74 \%$, respectively.
\end{abstract}

\section{INTRODUCTION}

The intensification of fish production in Egypt has made it essential to develop complete and supplemental diets for use in aquaculture. Traditionally, fish meal is the preferred dietary protein source for many farmed fish species and is valued for its amino acid balance, vitamin content, palatability and unidentified growth factors (Tacon, 1993). However, the increasing cost of fish meal 
has restricted its use as a protein source for fish diets. Therefore, plant proteins appear to be the most appropriate alternative for fish meal in fish diets.

Various oilseed meals are produced in Egypt on a large scale as byproducts of the edible oil industry. These include cottonseed, sunflower, soybean and linseed meals. The efficiency of various alternative protein sources as partial or complete replacement for fish meal has been individually evaluated in fish diets, e.g. sunflower meal (El-Saidy \& Gaber, 2002a ; Ibrahim, 2007), soybean (El-Saidy \& Gaber, 2002b ; Soltan et al., 2001), linseed meal (El-Saidy \& Gaber, 2001 and Soltan, 2005a) canola (Soltan, 2005b) and cottonseed meal (Saudi, 2008). Individually, these plant by-product meals are fairly rich in protein and favourable essential amino acid profiles, but they are deficient in one or more essential amino acids and contained various quantities of anti-nutritional factors (NRC, 1993).

Some studies have also stressed that a mixture of plant protein sources is more appropriate to obtain adequate amino acid profile compared to the incorporation of a single plant protein source (Watanabe et al., 1995; Regost et al., 1999). Recently, comparative studies conducted in rainbow trout, turbot, sea bass and sea bream attempted to completely substitute fish meal by a mixture of plant proteins. All diets were supplemented with L-amino acids to meet the amino acid needs estimated for rainbow trout (NRC, 1993). Results were disappointing and compared to a control diet, growth retardation was observed even in rainbow trout. Beside the effects of known or unknown anti-nutritional factors, a deficiency of one or more amino acid was suspected, suggesting that supplementation of diet according to amino acids needs available in NRC (1993) was not sufficient. Mambrini \& Kaushik (1995) suggested that amino acid profile of fish meal reflects well the fish amino acid needs which could imply to supplement plant protein based diets at higher levels than required by NRC (1993).

The present, study was carried out to evaluate the nutritional value of combinations of plant proteins in order to replace fish meal in tilapia diets.

\section{MATERIALS AND METHODS}

Nile tilapia fingerlings were obtained from The World Fish Center at Abbassa, Sharkya Governorate, Egypt and acclimated to laboratory conditions in 1700-L fibreglass tanks. The feeding trial was performed at the Fish Nutrition Lab (Faculty of Agriculture, Benha University, Egypt).

Diets and feeding regime: Eight experimental diets were formulated (Table 1) to be isonitrogenous $(30 \% \mathrm{CP})$ and isocaloric $\left(2700 \mathrm{Kcal} \mathrm{ME} \mathrm{kg}{ }^{-1}\right)$. Cottonseed, sunflower, linseed, seasme meals were obtained from local market, while canola meal was obtained from the Agricultural Research Center, Dokki, Egypt and these meals were mixed (20\% for each) to obtain the PPM. Fish meal in the control diet was replaced (based on protein content) by PPM at 15, 30, 45, 60, 75, 90 and $100 \%$ levels. In preparing the diets, dry ingredients were first ground to a small 
particle size and mixed thoroughly with added water to obtain a $30 \%$ moisture level. Diets were passed through a mincer with diameter of $2 \mathrm{~mm}$ to produce pellets and were sun-dried for 3 days.

Culture conditions: At the beginning of the experiment, 24 glass aquaria $(100 \times$ $50 \times 40 \mathrm{~cm})$ were supplied with freshwater $\left(180 \mathrm{~L}\right.$ for each) at a rate of $1 \mathrm{~L} \mathrm{~min}{ }^{-1}$ with supplemental aeration and each aquarium was stocked by 20 fish (2.61- 2.71 g). Fish were fed the diets at a daily rate of $10 \%$ (during the $1^{\text {st }}$ month), then reduced to $7 \%\left(2^{\text {nd }}\right.$ month $)$ and $4 \%\left(3^{\text {rd }}\right.$ month $)$ of total biomass. Fish were fed the experimental diets 6 days/week (twice daily at 9.00 am and $3.00 \mathrm{pm}$ ). The amount of feed was bi-weekly adjusted according to the changes in body weight throughout the experimental period (90 days).

Table (1): Composition and proximate analysis of the experimental diets.

\begin{tabular}{|c|c|c|c|c|c|c|c|c|}
\hline \multirow[b]{2}{*}{ Ingredients } & \multicolumn{8}{|c|}{ Diets } \\
\hline & D1 & D2 & D3 & D4 & D5 & D6 & D7 & D8 \\
\hline Fish meal $(72 \% \mathrm{CP})$ & 16 & 13.6 & 11.2 & 8.8 & 6.4 & 4.0 & 1.6 & 0 \\
\hline Soybean meal (44\%CP) & 35 & 35 & 35 & 35 & 35 & 35 & 35 & 35 \\
\hline Plant protein mixture $(33 \% \mathrm{CP})$ & 0 & 5.1 & 10.2 & 15.3 & 20.4 & 25.5 & 30.6 & 35 \\
\hline Yellow corn & 32 & 32 & 32 & 32.6 & 31.2 & 28.5 & 25.8 & 22 \\
\hline Wheat bran & 10 & 7.3 & 4.6 & 1.3 & 0 & 0 & 0 & 0 \\
\hline Vegetable oil & 4 & 4 & 4 & 4 & 4 & 4 & 4 & 5 \\
\hline Vit. \& Min. Mixture & 2.5 & 2.5 & 2.5 & 2.5 & 2.5 & 2.5 & 2.5 & 2.5 \\
\hline $\mathrm{Cr} 2 \mathrm{O} 3$ & 0.5 & 0.5 & 0.5 & 0.5 & 0.5 & 0.5 & 0.5 & 0.5 \\
\hline Sum & 100 & 100 & 100 & 100 & 100 & 100 & 100 & 100 \\
\hline \multicolumn{9}{|c|}{ Proximate analysis (determined on dry matter basis) } \\
\hline Dry matter $(\mathrm{DM})$ & 96.55 & 95.87 & 96.12 & 97.46 & 96.67 & 95.77 & 96.13 & 96.45 \\
\hline Crude protein $(\mathrm{CP})$ & 30.80 & 30.53 & 30.27 & 30.00 & 29.70 & 29.73 & 29.80 & 29.50 \\
\hline Ether extract (EE) & 6.24 & 6.81 & 6.02 & 5.87 & 5.58 & 6.11 & 6.00 & 6.32 \\
\hline Crude fiber (CF) & 9.16 & 9.24 & 9.13 & 9.35 & 9.52 & 9.50 & 9.54 & 9.73 \\
\hline Ash & 8.25 & 8.46 & 8.55 & 8.56 & 8.44 & 8.88 & 8.90 & 8.99 \\
\hline $\mathrm{NFE}^{2}$ & 45.55 & 44.96 & 46.03 & 46.22 & 46.76 & 45.78 & 45.76 & 45.46 \\
\hline $\mathrm{ME}^{3}$ (Kcal/kg diet) & 2712 & 2705 & 2714 & 2736 & 2715 & 2706 & 2717 & 2710 \\
\hline $\mathrm{P} / \mathrm{E} \mathrm{ratio}^{4}$ & 113.57 & 112.87 & 111.53 & 109.65 & 109.39 & 109.87 & 109.68 & 108.86 \\
\hline
\end{tabular}

1-Vitamin \& mineral mixture/kg premix : Vitamin $\mathrm{D}_{3}, 0.8$ million IU; A, 4.8 million IU; E, 4 g; K, 0.8 g; B1, 0.4 g; Riboflavin, 1.6 g; B6, 0.6 g, B12, 4 mg; Pantothenic acid, 4 g; Nicotinic acid, $8 \mathrm{~g}$; Folic acid, 0.4 g Biotin, $20 \mathrm{mg}$, Mn, $22 \mathrm{~g}$; Zn, $22 \mathrm{~g}$; Fe, $12 \mathrm{~g}$; Cu, 4 g; I, 0.4 g, Selenium, $0.4 \mathrm{~g}$ and $\mathrm{Co}, 4.8 \mathrm{mg}$.

2-Nitrogen free extract (NFE) $=100-(\mathrm{CP}+\mathrm{EE}+\mathrm{CF}+\mathrm{Ash})$

3- Metabolizable energy was calculated from ingredients based on NRC (1993) values for tilapia. 4- Protein to energy ratio in $\mathrm{mg}$ protein/kcal ME.

Digestibility trial: A chromic oxide marker was included $(0.5 \%)$ in all experimental diets. During the last three weeks of the experiment, fish provided the experimental diets and feces were collected daily as described by Hajen et al. (1993). Feeds and collected feces were dried to a constant weight. Proximate analysis of the diets and feces were conducted in 6 triplicates for dry matter (DM) crude protein (CP), ether extract (EE), crude fiber (CF) and ash. Chromic oxide levels were determined in the diets and feces (Fenton \& Fenton, 1979) and 
apparent digestibility coefficients for the nutrients were calculated according to NRC (1993) by the equation:

$100-100[(\%$ marker in diet $/ \%$ marker in feces $) \times(\%$ nutrient in diet $/ \%$ nutrient in feces)].

Growth and feed utilization parameters: Growth performance and feed utilization parameters were determined according to Cho \& Kaushik (1985) as follows:

Specific growth rate $(\mathrm{SGR})=[(\mathrm{LnW} 2-\mathrm{LnW} 1) / \mathrm{t}] \times 100$ Where:- $\mathrm{Ln}=$ the natural $\log , \mathrm{W} 1=$ initial fish weight; $\mathrm{W} 2=$ the final fish weight in "grams" and $\mathrm{t}=$ period in days.

Feed conversion ratio $(\mathrm{FCR})=$ feed intake $(\mathrm{g}) /$ wet weight gain $(\mathrm{g})$, Protein efficiency ratio $($ PER $)=$ weight gain $(\mathrm{g}) /$ protein intake $(\mathrm{g})$,

Water quality: Parameters of water quality were determined according to the methods of APHA (1992). Ammonia and nitrite were measured at weekly intervals, while water temperatures were recorded daily in each tank using a mercury thermometer suspended at 30-cm water depth. Also, dissolved oxygen was measured daily by oxygen meter and $\mathrm{pH}$ by $\mathrm{pH}$ meter.

Blood samples and liver function: Blood samples were obtained from fish at the end of experimental period. Five fish per tank were randomly taken and anaesthetized by ethylene glycol mono-phenol ether. Blood samples were collected from the caudal vein using heparinized 27-gauge needles and tuberculin syringes. Hematocrit $(\mathrm{Ht})$ was determined using the micro-Ht method described by Brown (1988). Hemoglobin $(\mathrm{Hb})$ was determined using the total $\mathrm{Hb}$ kit (Sigma Diagnostics, Sigma, St Louis, MO. USA) which is a standardized procedure using the cyanomethemoglobin method. Liver was removed, homogenized and assigned for determination of Aspartate transaminase (AST) and Alanine transaminase (ALT) according to Reitman and Frankel, (1957).

Chemical analysis: At termination of the experiment, three fish were randomly sampled from each tank and subjected to the chemical analysis of whole fish body. Chemical analysis of fish, diets and feces were determined according to the methods of AOAC (1990).

Statistical analysis: The statistical analysis of data was carried out by applying the computer program, SAS (1996) by adopting the model: $Y_{i j}=\mu+\alpha_{i}+e_{i j}$ Where, $Y_{i j}=$ the observation on the $j^{\text {th }}$ fish eaten the $i^{\text {th }}$ diet; $\mu=$ overall mean, $\alpha_{i}=$ the effect of $i^{\text {th }}$ diet and $\mathrm{e}_{\mathrm{ij}}=$ random error.

\section{RESULTS}

Water quality: During the whole experimental period, water temperature ranged from 23.15 to $30.16^{\circ} \mathrm{C}$, dissolved oxygen fom 3.55 to $7.23 \mathrm{mg} \mathrm{L}^{-1}$, $\mathrm{pH}$ from 7.71 to 7.89 and total ammonia from 0.12 to $0.16 \mathrm{mg} \mathrm{L}^{-1}$. There were no significant $(\mathrm{P}<0.05)$ differences in water quality parameters among treatments during the whole experimental period, indicating that the experimental diets had no harmful effects on the surrounding water quality of experimental fish. 
Feed utilization: The highest feed intake (FI) and the best feed conversion ratio (FCR) and protein efficiency ratio (PER) were obtained for fish fed the control diet and these parameters did not significantly affected when 15,30 or $45 \%$ of FM was replaced by PPM. The highest replacing levels $(60,75,90$ or $100 \%)$ significantly adversed FCR and significantly reduced FI and PER (Table 2).

Table (2): Feed efficiency of Nile tilapia as affected by replacing fish meal by a mixture of plant protein sources.

\begin{tabular}{lccc}
\hline Experimental diets & FI (g/fish) & FCR & PER \\
\hline PPM0 (Control) & $41.50 \mathrm{a}$ & $1.50 \mathrm{c}$ & $2.17 \mathrm{a}$ \\
PPM15 & $40.94 \mathrm{a}$ & $1.53 \mathrm{c}$ & $2.14 \mathrm{a}$ \\
PPM30 & $40.93 \mathrm{a}$ & $1.54 \mathrm{c}$ & $2.15 \mathrm{a}$ \\
PPM45 & $40.86 \mathrm{a}$ & $1.58 \mathrm{c}$ & $2.11 \mathrm{a}$ \\
PPM60 & $37.44 \mathrm{~b}$ & $1.72 \mathrm{~b}$ & $1.96 \mathrm{~b}$ \\
PPM75 & $36.12 \mathrm{~b}$ & $1.80 \mathrm{~b}$ & $1.83 \mathrm{~b}$ \\
PPM90 & $34.66 \mathrm{~b}$ & $1.90 \mathrm{~b}$ & $1.76 \mathrm{~b}$ \\
PPM100 & $30.66 \mathrm{c}$ & $2.17 \mathrm{a}$ & $1.56 \mathrm{c}$ \\
\pm SE & \pm 0.45 & \pm 0.02 & \pm 0.03 \\
Probability & 0.0061 & 0.0089 & 0.0046 \\
\hline
\end{tabular}

Means followed by the different letters in each row for each trait are significantly different $(\mathrm{P}<0.05)$.

Apparent nutrient digestibility: Compared to control group, replacing up to $45 \%$ of FM by PPM did not significantly $(\mathrm{P}<0.05)$ change apparent digestibility coefficient $(\mathrm{ADC})$ for $\mathrm{DM}, \mathrm{CP}$ and $\mathrm{EE}$ while the highest replacing levels significantly $(\mathrm{P}<0.05)$ decreased $\mathrm{ADC}$ for $\mathrm{DM}, \mathrm{CP}$ and $\mathrm{EE}$. It is interesting to note that, the highest NFE digestibility coefficient was observed for the diets PPM0 and PPM15 and the lowest value observed for the diet PPM100, where FM was completely replaced by PPM (Table 3 ).

Table (3): Apparent digestibility coefficients (ADC) for different nutrients in the experimental diets.

\begin{tabular}{lllll}
\hline Diets & DM & CP & EE & NFE \\
\hline PPM0(control) & $83.56 \mathrm{a}$ & $81.25 \mathrm{a}$ & $81.65 \mathrm{a}$ & $75.25 \mathrm{a}$ \\
PPM15 & $82.34 \mathrm{a}$ & $81.85 \mathrm{a}$ & $81.44 \mathrm{a}$ & $76.63 \mathrm{a}$ \\
PPM30 & $83.74 \mathrm{a}$ & $82.69 \mathrm{a}$ & $80.24 \mathrm{a}$ & $71.24 \mathrm{~b}$ \\
PPM45 & $82.67 \mathrm{a}$ & $80.89 \mathrm{a}$ & $78.89 \mathrm{a}$ & $71.76 \mathrm{~b}$ \\
PPM60 & $80.15 \mathrm{~b}$ & $77.57 \mathrm{bc}$ & $75.65 \mathrm{~b}$ & $70.34 \mathrm{~b}$ \\
PPM75 & $76.90 \mathrm{c}$ & $74.84 \mathrm{bc}$ & $75.24 \mathrm{~b}$ & $70.64 \mathrm{~b}$ \\
PPM90 & $75.57 \mathrm{c}$ & $73.17 \mathrm{c}$ & $75.65 \mathrm{~b}$ & $71.68 \mathrm{~b}$ \\
PPM100 & $76.71 \mathrm{c}$ & $73.38 \mathrm{c}$ & $74.22 \mathrm{~b}$ & $68.64 \mathrm{c}$ \\
\pm SE & \pm 1.88 & \pm 1.67 & \pm 2.33 & \pm 1.56 \\
Probability & 0.0511 & 0.0346 & 0.0308 & 0.0505 \\
\hline
\end{tabular}

Means followed by the different letters in each row for each trait are significantly different $(\mathrm{P}<0.05)$.

Growth performance: As described in Table (4), replacing of FM by PPM protein up to $45 \%$ in tilapia diets had no significant effect on growth 
performance parameters including $\mathrm{BW}, \mathrm{BL}, \mathrm{WG}$ and SGR, while the highest replacing levels significantly $(\mathrm{P}<0.01)$ reduced these parameters. The worst growth performance parameters were obtained for fish fed the diet PPM100. In contrast, no significant difference was observed among fish fed the diets PPM, PPM15, PPM30 and PPM45.

Table (4): Growth performance of Nile tilapia as affected by replacing fish meal by a mixture of plant proteins

\begin{tabular}{|c|c|c|c|c|c|c|c|}
\hline \multirow[t]{2}{*}{ Experimental diets } & \multirow[t]{2}{*}{ No. } & \multicolumn{2}{|c|}{ BW (G) } & \multicolumn{2}{|c|}{ BL (cm) } & \multirow[t]{2}{*}{ WG (g/fish) } & \multirow[t]{2}{*}{ SGR } \\
\hline & & Initial & Final & Initial & Final & & \\
\hline PPM0 (Control) & 60 & 2.61 & $30.34 \mathrm{a}$ & 5.60 & $11.60 \mathrm{a}$ & $27.73 \mathrm{a}$ & $2.73 \mathrm{a}$ \\
\hline PPM15 & 60 & 2.66 & $29.46 \mathrm{a}$ & 5.57 & $11.44 \mathrm{a}$ & $26.80 \mathrm{a}$ & $2.67 \mathrm{a}$ \\
\hline PPM30 & 60 & 2.68 & $29.30 \mathrm{a}$ & 5.70 & $11.34 \mathrm{a}$ & $26.62 \mathrm{a}$ & $2.66 \mathrm{a}$ \\
\hline PPM45 & 60 & 2.61 & $28.49 \mathrm{a}$ & 5.60 & $11.33 \mathrm{a}$ & $25.88 \mathrm{a}$ & $2.66 \mathrm{a}$ \\
\hline PPM60 & 60 & 2.67 & $24.43 \mathrm{~b}$ & 5.70 & $10.80 \mathrm{~b}$ & $21.76 \mathrm{~b}$ & $2.46 \mathrm{~b}$ \\
\hline PPM75 & 60 & 2.65 & $22.76 \mathrm{bc}$ & 5.63 & $10.73 \mathrm{~b}$ & $20.11 \mathrm{~b}$ & $2.39 \mathrm{~b}$ \\
\hline PPM90 & 60 & 2.67 & $20.90 \mathrm{c}$ & 5.63 & $10.64 \mathrm{~b}$ & $18.23 \mathrm{c}$ & $2.29 \mathrm{c}$ \\
\hline PPM100 & 60 & 2.71 & $16.84 \mathrm{~d}$ & 5.57 & $9.76 \mathrm{c}$ & $14.13 \mathrm{c}$ & $2.03 \mathrm{c}$ \\
\hline $\pm S E$ & & \pm 0.21 & \pm 1.23 & \pm 0.46 & \pm 1.67 & \pm 0.68 & \pm 0.07 \\
\hline Probability & & 0.2881 & 0.0013 & 0.4325 & 0.0013 & 0.0056 & 0.0036 \\
\hline
\end{tabular}

Means followed by the different letters in each row for each trait are significantly different $(\mathrm{P}<0.05)$.

Blood parameters and liver function: Crompared to the control group, hemoglobin and hematocrit values decreased proportionally with increasing incorporation level of PPM in the experimental diets (Table 5). All fish fed diets with PPM protein replacement had significantly $(\mathrm{P}<0.001)$ lower hematocrit and hemoglobin values compared to the control group and the opposite trend was observed for the levels of liver enzyme (ALT and AST), where the increased levels of PPM in the diet significantly increased the levels of ALT and AST.

Proximate analysis of fish whole-body: DM and CP of whole body showed some variation (but not significant) and increased with increasing level of PPM in diets (Table 6). The whole-body content of EE and ash significantly $(\mathrm{P}<0.05)$ increased with increasing the PPM content of tilapia diets.

Table (5): Blood parameters and liver function of fish groups fed the experimental diets.

\begin{tabular}{|c|c|c|c|c|}
\hline Diets & Hemoglobin & Hematocrite & ALT & AST \\
\hline PPM0(control) & $7.10 \mathrm{a}$ & $26.90 \mathrm{a}$ & $43.17 \mathrm{~d}$ & $50.00 \mathrm{~d}$ \\
\hline PPM15 & $5.37 \mathrm{c}$ & $19.80 \mathrm{~b}$ & $43.33 \mathrm{~d}$ & $65.67 \mathrm{c}$ \\
\hline РPM30 & $5.50 \mathrm{bc}$ & $11.87 \mathrm{c}$ & $47.67 \mathrm{c}$ & $61.67 \mathrm{c}$ \\
\hline PPM45 & $5.27 \mathrm{c}$ & $21.00 \mathrm{~b}$ & $52.33 \mathrm{~b}$ & $60.00 \mathrm{c}$ \\
\hline PPM60 & $4.23 \mathrm{e}$ & $13.50 \mathrm{c}$ & $56.67 \mathrm{ab}$ & $77.33 \mathrm{a}$ \\
\hline PPM75 & $5.63 \mathrm{~b}$ & $13.50 \mathrm{c}$ & $58.00 \mathrm{ab}$ & $76.33 \mathrm{a}$ \\
\hline РPM90 & $4.77 \mathrm{~d}$ & $14.37 \mathrm{c}$ & $56.77 \mathrm{ab}$ & $70.00 \mathrm{~b}$ \\
\hline PPM100 & $5.43 \mathrm{bc}$ & $21.37 \mathrm{~b}$ & $63.00 \mathrm{a}$ & $75.33 \mathrm{a}$ \\
\hline $\pm S E$ & \pm 0.07 & \pm 0.76 & \pm 0.46 & \pm 0.67 \\
\hline Probability & 0.0001 & 0.0001 & 0.0001 & 0.0001 \\
\hline
\end{tabular}

Means followed by the different letters in each row for each trait are significantly different $(\mathrm{P}<0.05)$. 
Economical evaluation: As described in Tables 3 and 4, replacement of FM by PPM up to $45 \%$ in tilapia diets did not significantly affect all growth and feed utilization parameters and reduced feed costs $/ \mathrm{kg}$ diet and feed costs $/ \mathrm{kg}$ weight gain by 11.40 and $6.74 \%$, respectively (Table 7 ). The highest replacing levels significantly reduced all growth and feed utilization parameters and also reduced feed costs $/ \mathrm{kg}$ diet. Complete replacement of FM by PPM increased feed costs $/ \mathrm{kg}$ weight gain by $6.52 \%$.

Table (6): Proximate analysis of fish whole-body (based on dry matter)

\begin{tabular}{lccll}
\hline Experimental diets & DM & CP & EE & Ash \\
\hline PPM0(control) & 25.18 & 68.58 & $13.12 \mathrm{a}$ & $11.23 \mathrm{~b}$ \\
PPM15 & 25.23 & 67.72 & $13.26 \mathrm{a}$ & $11.93 \mathrm{~b}$ \\
PPM30 & 25.95 & 67.20 & $14.74 \mathrm{ab}$ & $12.02 \mathrm{ab}$ \\
PPM45 & 27.52 & 66.67 & $14.36 \mathrm{ab}$ & $12.80 \mathrm{ab}$ \\
PPM60 & 25.91 & 66.12 & $15.22 \mathrm{ab}$ & $12.59 \mathrm{ab}$ \\
PPM75 & 26.52 & 66.11 & $16.89 \mathrm{~b}$ & $12.25 \mathrm{ab}$ \\
PPM90 & 27.16 & 66.79 & $15.87 \mathrm{~b}$ & $15.81 \mathrm{~b}$ \\
PPM100 & 27.76 & 67.78 & $16.39 \mathrm{~b}$ & $15.12 \mathrm{a}$ \\
\pm SE & \pm 1.88 & \pm 1.85 & \pm 0.86 & \pm 0.97 \\
Probability & 0.0761 & 0.0881 & 0.0431 & 0.0511 \\
\hline
\end{tabular}

Means followed by the different letters in each row for each trait are significantly different $(\mathrm{P}<0.05)$.

Table (7): Feed costs (L.E) for producing one $\mathrm{kg}$ weight gain as affected by the experimental diets.

\begin{tabular}{|l|c|c|c|c|c|c|c|}
\hline Diets & $\begin{array}{c}\text { Costs } \\
\text { L.E)/ton }\end{array}$ & $\begin{array}{c}\text { Relative to } \\
\text { control \% }\end{array}$ & $\begin{array}{c}\text { Decrease in } \\
\text { feed cost (\%) }\end{array}$ & FCR & $\begin{array}{c}\text { Feed costs * } \\
\text { (L.E)/kg } \\
\text { Weight gain }\end{array}$ & $\begin{array}{c}\text { Decrease in Feed } \\
\text { Relative to } \\
\text { control \% }\end{array}$ & $\begin{array}{c}\text { costs* (L.E)/kg } \\
\text { Weight gain }\end{array}$ \\
\hline PPM0 & 3065.0 & 100.00 & 0 & 1.50 & 4.60 & 100 & 0 \\
\hline PPM15 & 2948.0 & 96.18 & 3.82 & 1.53 & 4.51 & 98.04 & 1.96 \\
\hline PPM30 & 2831.0 & 92.37 & 7.63 & 1.54 & 4.36 & 94.78 & 5.22 \\
\hline PPM45 & 2715.5 & 88.60 & 11.40 & 1.58 & 4.29 & 93.26 & 6.74 \\
\hline PPM60 & 2595.0 & 84.67 & 15.33 & 1.72 & 4.46 & 96.96 & 3.04 \\
\hline PPM75 & 2471.3 & 80.63 & 19.37 & 1.80 & 4.45 & 96.74 & 3.26 \\
\hline PPM90 & 2347.5 & 76.59 & 23.41 & 1.90 & 2.46 & 96.96 & 3.04 \\
\hline PPM100 & 2260.0 & 73.74 & 26.26 & 2.17 & 4.90 & 106.52 & +6.52 \\
\hline
\end{tabular}

* Feed costs $/ \mathrm{kg}$ weight gain $=\mathrm{FCR} \times$ costs of $\mathrm{kg}$ feed.

Local market price (L.E./ton) for feed ingredients used for formulating the experimental diets when the experiment was started; fish meal 8000 LE/ton, yellow corn 1250; soybean meal 2500; plant protein mixture 2000; wheat bran 1000; corn oil $4000 \mathrm{LE} /$ ton and vit.\& Min. Mixture $10 \mathrm{LE} / \mathrm{kg}$.

\section{DISCUSSION}

Since fish are poikiothermic, their food requirement will be related to activity and hence to water temperature. Water temperature expressed as mean values ranged from 23.15 to $30.16^{\circ} \mathrm{C}$, dissolved oxygen $\left(4.55-6.23 \mathrm{mg} \mathrm{L}^{-1}\right) ; \mathrm{pH}$ (7.71 - 7.89), total ammonia $\left(0.12-0.16 \mathrm{mg} \mathrm{L}^{-1}\right)$. These values are in consistence with the means needed for tilapia growth (Stickney, 1979). These means 
indicated that the experimental diets have no harmful, effect on the surrounding water, where the experimental tilapia had been stocked. Therfore, all fish were in normal activity.

The experimental diets were formulated to be almost iso-nitrogenous and iso-caloric. Accordingly, any difference in the performance of fish received such diets could be attributed to the quality and feeding value of the tested materials and levels used. Digestibility values are important parameters to consider in the diet formulation and in determining the untilization of a feed. Feedstuffs which are poorly digested would be of limited value to an animal.

The obtained results clearly showed that, the replacement of up to $45 \%$ FM by PPM allowed FI, FCR, PER and ADC for DM, CP and EE similar to those exhibited by the control groups (FM based diet) and the same trend was also obtained for growth parameters (BW, BL, WG and SGR). The highest replacing levels (more than 45\%) significantly reduced FI, FCR, PER and the $\mathrm{ADC}$ for the different nutrients (DM, CP, and EE) and also negatively affected growth parameters (BW, BL, WG and SGR). This result suggests that the apparent protein digestibility for PPM is lower than that of FM for Nile tilapia.

Possible reasons for the reduced feed utilization, digestibility and growth parameters could be the highest replacing levels of FM by PPM (more than $45 \%$ ). The high-crude fiber and poor platability of PPM might reduce FI and adversed FCR and PER (Luo et al., 2006). Other possible explanation for the low feed utilization, digestibility and growth performance at increasing levels of FM substitution by PPM may be resulting from the presence of identified or unidentified anti-nutritional factors in PPM which increased in the diet with increasing the substitution of FM by PPM that reduced feed utilization, digestibility coefficients for the different nutrients and fish growth.

Mucilage in linseed (5-8\%) could increase the delay of diet retention in stomach, affecting FI through feedback on satiety signals. Also, mucilage has a large capacity to bind to water and increases intestinal viscosity, thus reducing nutrient digestibility (Fedeniuk \& Biliaderis, 1994).

Canola meal contains phenolic compounds (such as sinapin and tannin) that may reduce palatability (McCurdy \& March, 1992) and reduce protein digestibility (Krogdahl, 1989). Canola meal also contains glucosinolates which act as anti-thyroid factors (Teskeredzic et al., 1995). The high fiber content of canola meal may reduce protein and energy digestibility (Higgs et al., 1983).

Phytic acid (present in linseed meal) negatively affects the utilization of minerals which can be seen by its ability to bind up to $75 \%$ of all phosphorus (NRC, 1998). It can chelate di- and tri- valent metals including calcium, magnesium, zinc and iron into compounds that are less easily absorbed in the intestine. Phytic acid also has the ability to nonselectively bind to protein and inhibit activities of a number of digestive enzymes such as pepsin, trypsin and alpha-amylase (Liener, 1994). Cyanogenic compounds in linseed meal are a toxic for fish (Poulton, 1989). 
Cottonseed meal usually contains 0.4 to $1.7 \%$ gossypol. Free gossypol, when present in large quantity in the diet, has been shown to be toxic to monogastric animals including fish (Barros et al., 2002). Consequently, the increased levels of PPM in the diets may reduce growth, feed intake, feed and protein utilization, digestibilities of the different nutrients and histological changes in the liver and kidney (Kissil et al., 1997).

The finding that the incorporation of more than $45 \%$ of FM by PPM significantly decreased fish growth in agreement with the poor growth reported by Fournier et al. (2004) who found that replacement of FM by a PPM (lupin, corn gluten and wheat gluten meal) in the diets of juvenile turbot (Psetta maxima) up to $50 \%$ did not significantly affect growth rate, while the highest replacing levels $(75$ or $100 \%)$ significantly reduced growth rate. On the other hand, El-Saidy \& Gaber (2003) substituted FM by a PPM (soybean, cotton seed, sunflower and linseed meal) in diets of Nile tilapia. They found that the partial or complete replacement of FM by PPM exhibited growth performance not differing significantly from the fish fed the control diet. Moreover, Lee et al. (2002) with rainbow trout, Oncorhynchus mykiss found that FM could be entirely replaced by a mixture of plant proteins (cottonseed meal, soybean meal) and animal by-product proteins without adverse effect on growth rate and feed utilization. Such different findings reflect the fact that the utilization of PPM differs considerably, depending on the kind and quality of meals incorporated in the diets.

The hematological variables of hemoglobin and hematocrite, taken as an indicator of the rate of hemoglobin synthesis to red cell formation and erythrocyte fragility (Barraza et al., 1991). The hemoglobin $\left(7.10 \mathrm{~g} \mathrm{dL}^{-1}\right)$ and hematocrit $(26.90 \%)$ levels of control group in our study were within the normal levels (Sun et al., 1995). Hemoglobin and hematocirt levels in fish fed diets containg $60 \%$ PPM protein were about half lower than the control group. The lower hemeoglobin and hematocrit levels in Nile tilapia fed PPM-containing diets is thought to be due to binding of phytic acid and gossypol molecules and the other toxic factors in PPM to minerals (iron) and/or amine group of amino acids, causing their low availabilities in the body and increased erythrocyte fragility.

ALT and AST enzymes are two of the thousand kinds of liver enzymes, and a kind of transferase. They have the function of transferring amino group from alpha-amino acids to alpha-keto acids. Large amounts of ALT and AST released into blood mostly due to liver cell damage. Thus, detection of serum level of ALT and AST tells the existence of liver cell damage. Compared to control serum level of transferase enzymes (ALT and AST) significantly increased with each increase of PPM in the experimental diet. Cellular damage indicators (ALT and AST) significantly $(\mathrm{P}<0.001)$ increased as PPM increased in the diets, indicating the abnormal liver function and this may be due to increasing the identified or un-identified anti-nutritional and toxic factors 
presented in PPM. The increasing levels of toxic factors as the level of PPM increased in the diets showed the degree of liver cells damage.

Concerning proximate whole-body composition, DM and CP contents of Nile tilapia were not influenced by dietary protein source. Similarly, El-Saidy \& Gaber (2003) in Nile tilapia, Regost et al. (1999) in turbot, Moyano et al. (1992) in rainbow trout, Pongmaneerat et al. (1993) in carp and Shimeno et al. (1993) in yellowtail did not find any effects of PPM on the whole-body protein content. In contrast to our results, they also found that the whole-body fat and ash contents had not significantly varied when compared to the control. This is expected as fish in all treatments did not grow essentially at the same rate. Barros et al. (2000) and Yildirim et al. (2003) reported that body fat content is closely related to weight gain and inversely related to body moisture content.

From the economic standpoint, replacement of FM with cheaper PPM in a practical diet for Nile tilapia can alleviate the problem of low FM availability and high cost. Feeding costs in fish production is about $50 \%$ of the total production costs (Collins \& Delmendo, 1979). All other costs in the present study are constant, therefore, the feeding costs required to produce one kg gain in weight could be used to compare the different experimental treatments. The calculated figures showed that the cost of one ton feed mixture was reduced in all replacing levels of FM by PPM and the replacing level $45 \%$ reduced feeding costs by $11.4 \%$ and decreased feed costs $/ \mathrm{kg}$ weight gain by $6.74 \%$. In this respect, ElSaidy \& Gaber (2003) found that, partial or complete replacement of FM by a mixture of plant protein sources significantly reduced incidence costs and improved profit indices compared to the basal diet.

The present study indicted the potential of PPM for inclusion in commercial Nile tilapia feeds, as well as being of immediate importance for feed production in Egypt. From the all aforementioned results, it could be detected that PPM could be utilized by tilapia safely and efficiently as alternative protein instead of $45 \%$ of FM without adverse effects on the performance of tilapia. This observation is supported by the ADC for DM, CP and EE values for diets containing mixtures of plant protein meals. In addition, these plant protein sources are locally available at much lower prices than imported FM.

Further research is required to determine the feasibility of improving the nutritional value of the available plant protein source and using PPM composed of different combinations of ingredients and to examine the effects of PPM use in diets on large sizes of fish under the field conditions. 


\section{REFERENCES}

AOAC, (Association of Official Analytical Chemists) (1990). Official Methods of Analysis. $15^{\text {th }}$ edn. AOAC, Arlington, VA, USA.

APHA, (1992). Standard methods for the examination of water and waste water. American Public Health Association. Washington. Dc.

Barraza, M. I.; Coppock, C. E.; Brooks, K. N.; Wilks, D. L.; Saunders, R. G. and Latimer, J. G. (1991). Iron sulfate and feed pelleting to detoxify free gossypol in cottonseed diets for dairy cattle. J. Dairy Sci., 74: 34573467.

Barros, M. M.; Lim, C.; Evans, J. J. and Klesius, P. H. (2000). Effects of iron supplementation to cottonseed meal diets on growth performance of channel catfish, Ictalurus punctatus. J. Appl. Aquacult., 10:65-86.

Barros, M. M.; Lim, C. and Klesius, P. H. (2002). Effect of soybean meal replacement by cottonseed meal and iron supplementation on growth immune response and resistance of channel catfish (Ictalurus punctatus) to Edwardsiella ictaluri challenge. Aquacult, 207: 263279.

Brown, B. A. (1988). Routine hematology procedures. In: Hematology: Principle and Procedures (ed, by B. A. Brown), pp. 7-122. Leo and Febiger, Philadelphia, PA. USA.

Cho, C. Y. and Kaushik, S. J. (1985). Effect of protein intake on metabolizable and net energy values of fish diets. In: Nutrition and Feeding in Fish ( ed. by C.B. Cowey, A.M. Mackie \& J.G. Bell ), pp. 95- 117. Academic Press, London, UK.

Collins, R. A. and Delmendo, M. N. (1979). Comparative economics of Aquacult in cages, raceways and enclosures. In: Advance in Aquacult, pp. 427-7. England, Fishing News Books.

El-Saidy, D. M. S. and Gaber, M. M. A. ( 2001). Linseed meal: its successful use as a partial and complete replacement for fish meal in practical diets for Nile tilapia Oreochromis niloticus. In: Proceedings of the Second International Conference on Animal Production and Health in Semi-Arid Areas (Fac. Envir. Agric. Sci., Suez Canal Univ., El-ArishNorth Sinai, Egypt. pp. 635- 643. 
El-Saidy, D. M. S. and Gaber, M. M. A. ( 2002a). Evaluation of dehulled sunflower meal as a partial and complete replacement for fish meal in Nile tilapia, Oreochromis niloticus (L.), diets. In: Proceedings of the First Annual Scientific Conference on Animal and Fish Production (Fac. Agric., Al-Mansoura Univ., Egypt. September 24-25, 2002, pp. 193-205.

El-Saidy, D. M. S. and Gaber, M. M. A. ( 2002b). Complete replacement of fish meal by soybean meal with dietary 1-lysine supplement for Nile tilapia Oreochromis niloticus, fingerlings. Journal of the World Aquacult Society, 33:297-306.

El-Saidy, D. M. S. and Gaber, M. M. A. ( 2003). Replacement of fish meal with a mixture of different plant protein sources in juvenile Nile tilapia Oreochromis niloticus (L.), diets. Aquacult. Research, 34:1119-1127.

Fedeniuk, R. W. and Biliaderis, C. G. (1994). Composition and physicochemical properties of linseed (Linum usitatissiumum) mucilage. J. Agric. Food Chem., 42:240-247.

Fenton, T. W. and Fenton, M. (1979). An improved procedure for the determination of chromic oxide in feed and feces. Can. J. Anim. Sci., 59:631-634.

Fournier, V.; Huelvan, C. and Desbruyeres, E. (2004). Incorporation of a mixture of plant feedstuffs as substitute for fish meal in diets of juvenile turbot (Psetta maxima). Aquacult., 236:451-465.

Hajen, W. E.; Higgs, D. A.; Beames, R. M. and Dosanjh, B. S. (1993). Digestibility of various feedstuffs by post-juvenile chinook salmon (Oncorhynchus ishawytscha) in sea water: I. Validation to technique. Aquacult., 112:321-332.

Higgs, D. A.; Fagerlund, U. H. M.; McBride, J. R.; Plotnikoff, M. D.; Dosanjh, B. S.; Markert, J. R. and Davidson, J. (1983). Protein quality of Alex canola meal for juvenile chinook salmon (Oncorhynchus tshawytscha) considering dietary protein and 3, 5, 3-triiodo-Lthyronine content. Aquacult., 34:213-238.

Ibrahim, M. S. (2007). Nutritional requirements for tilapia fry during nursing period. M. Sc. Thesis, Fac. Agric. Benha University, Egypt. 
Kissil, G. W.; Lupatsch, I.; Higgs, D. A. and Hardy, R. W. (1997). Preliminary evaluation of rapeseed protein concentrate as an alternative to fish meal in diets for gilthead seabream (Sparus aurata). Bamidgeh, 49:135-143.

Krogdahl, A. (1989). Alternative protein source from plants contain antinutrients affecting digestion in salmonids. In: M. Takeda and T. Watanabe (Eds.), Proc. of the $3^{\text {rd }}$ Intl. Symp. On Feeding and Nutrition in Fish, Laboratory of fish nutrition, Tokyo University of fisheries. Tokyo, Japan. pp. 253-261.

Lee, K. J.; Dabrowski, K.; Blom, J. H.; Bai, S. C. and Stromberg, P. C. (2002). A mixture of cottonseed meal, soybean meal and animal byproduct mixture as a fish meal substitute: growth and tissue gossypol enantiomer in juvenile rainbow trout (Onorhynchus mykiss). J. Anim. Physiol. Anim Nutr. (Berl),86(7-8):201-213.

Liener, I. E. (1994). Implications of antinutritional components in soybean foods. Crit. Rev. Food Sci. Nut., 34:31-67.

Luo, L., Xue, M.; Wu, X.; Cai, X.; Cao, H. and Liang, Y. (2006). Partial or total replacement of fishmeal by solvent-extracted cottonseed meal in diets of juvenile rainbow trout (Oncorhynchus mykiss).Aquacult Nutrition, $12: 418-424$.

Mambrini, M. and Kaushik, S. J. (1995). Indispensable amino acid requirements of fish: correspondence between quantitative data and amino acid profiles of tissue proteins. J. Appl. Ichthyol. 11: 240-247.

McCurdy, S. M. and March, B. E. (1992). Processing of canola meal for incorporation in trout and salmon diets. JAOCS, 69:213-220

Moyano F. J.; Cardenete, G. and De la Higuera, M. ( 1992). Nutritive value of diets containing high percentage of vegetable protein for trout, Oncorhynchus mykiss. Aquatic Living Resources, 5:23-29.

NRC (1993). National research Council. Nutrient Requirements of Fish. National Academy Press, Washington, DC, 114 pp.

NRC (1998). National Research Council. Nutrient Requirements of Swine, $10^{\text {th }}$ ed. National Academy of Science, Washington, DC, 189 pp. 
Pongmaneerat, J.; Watanabe, T.; Takeuchi, T. and Satoh, S. (1993). Use of different protein meals as partial or total substitution for fish meal in carp diets. Bulletin of Japanese Society of Scientific Fisheries, 59:1249-1257.

Poulton, J. E. (1989). Toxic compounds in plant foodstuffs. In: Food proteins: J. A. O. C. S., 31:381-401.

Regost, C.; Arzel, J. and Kaushik, S. J. ( 1999). Partial or total replacement of fish meal by corn gluten meal in diet for turbot, Psetta maxima. Aquacult., 180: 90-117.

Reitman, S. and Frankel, F. (1957). A colorimetric method for determination of oxaloacetic transaminase and serum glutamic puruvic transaminase.

A. J. Clin. Path., 28:56-60.

SAS (1996). SAS Procedure Guide "version 6.12 Ed”. SAS Institute Inc., Cary, $\mathrm{NC}$, USA.

Saudi, A. (2008). An experimental toxico-bromatological evaluation of feeding cottonseed meal and alpha-tocopherol to tilapia fish. Ph. D. Thesis, Fac. Agric. Benha University, Egypt.

Shimeno, S.; Masunoto, T.; Tujita T.; Mima, L. and Uenos, S. (1993). Alternative protein sources for fish meal in diets of young yellowtail. Nippon Suisan Gakkaishi, 59: 137- 143.

Soltan, M. A.; Ibrahim, M.K.; Fatma A. Hafez and Fath, El-Bab, A. F. (2001). Effect of partial and total replacement of fish meal by soybean meal on growth and proximate analysis of Nile tilapia (Oreochromis niloticus). Egypt. J. Nutr. \& Feeds, 4 (Special Issue):799-812

Soltan, M. A. (2005 a). Partial and total replacement of soybean meal by raw and heat treated linseed meal in tilapia diets. Egypt. J. Nutr. \& Feeds (Special Issue), 8(1):1091-1109.

Soltan, M. A. (2005 b). Potential of using raw and processed canola seed meal as an alternative fish meal protein source in diets for Nile tilapia (Oreochromis niloticus). . Egypt. J. Nutr. \& Feeds (Special Issue), 8(1):1111-1128.

Stickney, R. R. (1979). Principles of Warmwater Aquacult. Wiley-Interscience, New York, USA. 
Sun, L. T.; Chen, G. R. and Chang, C. F. (1995). Acute responses of blood parameters and comatose effects in salt-acclimated tilapias exposed to low temperature. Journal of thermal Biology, 20:299-306.

Tacon, A. G. (1993). Feed ingredients for warm water fish: fish meal and other feedstuffs. FAO. Circ., No. 856, FAO, Rome, 64 pp.

Teskeredzic, Z.; Higgs, D. A.; Dosanjh, B. S.; McBride, J. R.; Hardy, R. W.; Beames, R. M.; Jones, J. D.; Simell, M.; Vaara, T. and Brides, R. B. (1995). Assessment of undephytinized and dephytinized rapeseed protein concentrate as source of dietary protein for juvenile rainbow trout (Oncorhynchus mykiss). Aquacult., 131:261-277.

Watanabe, T.; Aoki, H.; Viyakarn, V.; Maita, M.; Yamagata, Y.; Satoh, S. and Takeuchi, T. (1995). Combined use of alternative protein sources as a partial replacement for fish meal in a newly developed soft-dry pellet for yellowtail,. Suisan Zoshoku, 43:511-520.

Yildirim, M.; Lim, C.; Wan, P. and Klesius, P. H. (2003). Growth performance and immune response of channel catfish (Ictalurus punctatus) fed diets containing graded levels of gossypol-acetic acid. Aquacult, 219:751-768. 